\title{
Knowledge Level about Thalassemia among High School Students in Pontianak City, West Kalimantan, Indonesia
}

\author{
Aisya Rezki Noeriman ${ }^{1 *}$ Iit Fitrianingrum ${ }^{2}$ Ita Armyanti ${ }^{3}$ \\ ${ }^{1}$ Medical School, Faculty of Medicine, Tanjungpura University. Jl. Prof. Hadari Nawaai, Pontianak, Kalimatan Barat, \\ Indonesia. 78121 \\ 2Department of Biology and Pathobiology, Faculty of Medicine, Tanjungpura University. Jl. Prof. Hadari Nawaai, Pontianak, \\ Kalimatan Barat, Indonesia. 78121 \\ ${ }^{3}$ Department of Medical Education and Bioethics, Faculty of Medicine, Tanjungpura University. Jl. Prof. Hadari Nawaai, \\ Pontianak, Kalimatan Barat, Indonesia. 78121
}

DATA OF ARTICLE:

Received: 19 Feb 2020

Reviewed: 20 May 2020

Revised: 29 May 2020

Accepted: 28 Jun 2020

*CORRESPONDENCE:

Noeriman.aisya@gmail.com

DOI:

10.18196/mm.200248

TYPE OF ARTICLE:

Research

\begin{abstract}
Thalassemia prevalence in Indonesia is still high. Genetic screening as an early detection effort for thalassemia is needed as a prevention effort, so knowledge about thalassemia is needed. There is no data related to the knowledge of high school students regarding thalassemia in Pontianak City, even though this data is important as initial data to formulate a thalassemia prevention program. This study aims to describe the level of knowledge about thalassemia among high school students. This research is descriptive. The sample was taken as many as 100 people with the propotionated stratified random sampling method based on the population of high school students in each district in Pontianak City. The results showed that almost half of the respondents had a low level of knowledge (49\%). Female students have a good level (27.1\%), more than male students (10\%). Sources of information used are online media $(44 \%)$, school lessons $(17 \%)$, health workers $(17 \%)$, counselor $(10 \%)$, relatives / friends (6\%) and print media (6\%). It can be concluded that the knowledge of high school students about thalassemia in Pontianak City is still lacking, so it is necessary to increase the dissemination of information about thalassemia through online media information sources.
\end{abstract}

Keywords: Level of knowledge, thalassemia, high school student.

Abstrak: Prevalensi Talasemia di Indonesia masih tinggi. Penapisan genetik sebagai upaya deteksi awal talasemia diperlukan sebagai upaya prevensi, sehingga dibutuhkan pengetahuan yang baik tentang Talasemia. Data terkait tingkat pengetahuan siswa SMA mengenai talasemia di Kota Pontianak tidak ada padahal data tersebut penting sebagai data awal untuk merumuskan program prevensi talasemia. Penelitian ini bertujuan untuk mengetahui gambaran tingkat pengetahuan siswa SMA di Kota Pontianak mengenai talasemia. Penelitian ini bersifat deskriptif. Sampel diambil sebanyak 100 orang dengan metode propotionated stratified random sampling berdasarkan jumlah populasi siswa SMA di tiap kecamatan di Kota Pontianak. Hasil menunjukkan hampir separuh responden memiliki tingkat pengetahuan kurang (49\%). Siswa perempuan memiliki tingkat pengetahuan baik $(27,1 \%)$, lebih banyak daripada siswa laki-laki (10\%). Sumber informasi yang digunakan adalah media daring (44\%), pelajaran sekolah (17\%), tenaga kesehatan (17\%), penyuluh (10\%), kerabat/teman (6\%) dan media cetak (6\%). Dapat disimpulkan bahwa pengetahuan siswa SMA mengenai talasemia di Kota Pontianak masih tergolong kurang, sehingga perlu peningkatan penyebaran informasi tentang talasemia melalui sumber informasi media daring.

Kata Kunci: tingkat pengetahuan, talasemia, siswa SMA 


\section{INTRODUCTION}

Thalassemia is an autosomal recessive genetic disease that cause abnormalities in the process of haemoglobin formation resulting destruction of red blood cells without adequate formation. ${ }^{1,2}$ Indonesia is one of the thalassemia belt country in Southeast Asia together with Thailand and Myanmar. ${ }^{2}$ The thalassemia belt is referring to countries with high prevalence of thalassemia. Several studies revealed the prevalence of thalassemia among teenagers. A thalassemia minor screening in Jatinangor, stated that $9.3 \%$ of all high school student respondents who are willing to participate in screening, are suspected with thalassemia beta minor. ${ }^{3}$ Data from Thalassemia Foundation and Association of Thalassemia Parents of Indonesia showed that there were 669 people (5.8\%) of the 12,038 general public examined through thalassemia screening from 2008 2017 who are carriers of the thalassemia gene. ${ }^{4}$ Data from RSUD dr. Soedarso Pontianak, a referral hospital in West Kalimantan Province, showed 1429 visits of thalassemia patients as outpatients throughout 2018.

Public understanding of thalassemia will improve the government program in controlling the new cases of thalassemia in coming year. Genetic screening is a thalassemia preventive strategy that can be done by premarital couples to find out the potential thalassemia genes come from the couple. Studies in several countries are shown that genetic screening has been put as a mandatory program as part of the national premarital screening program to reduce the rate of carrier marriage. ${ }^{5,6}$ High school students is a premarital age need to have a good understanding of thalassemia. A good knowledge is positively correlated with a person's attitude to genetic screening as a primary preventative measure against thalassemia.

Research on the level of thalassemia knowledge has been carried out in several regions in Indonesia 7,8 but similar research has never been done in Pontianak so that data on the level of knowledge about thalassemia, especially in high school students in Pontianak City is not ready. Thus, the study on high school students' knowledge about thalassemia need to be carried out.

The purpose of this study was to determine the high school students' level of knowledge in Pontianak City about thalassemia both in general and by gender. Besides, it is aimed to find out the source of information used by high school students in Pontianak City to obtain information about thalassemia.

\section{MATERIALS AND METHOD}

This research was a descriptive study conducted from October 2019-January 2020 in Pontianak City. A hundred high school students were chosen by using proportionated stratified random sampling method in each district of Pontianak. The inclusion criteria were: high school students in Pontianak City and willing to involved in the research. The thalassemia sufferers, thalassemia activists and respondents who have main families suffering from thalassemia were excluded. Data was collected by using questionnaires. The questionnaire consisted of two types of questions ( 5 multiple choice questions and 9 true-false questions). For each correct answer was given 1 score, while the wrong answer or not answered was given 0 . The total number of each respondent's score was grouped in four categories: excellent (total score 1214), good (total score 9-11), average (total values 68) and poor (0-5). Each respondent was given a code from R1-R100 then tabulated data processing was done using Microsoft Excel and IBM SPSS applications. The results of data processing were presented in the form of diagrams and graphs.

This study has approved by the Ethics Review Division of the Faculty of Medicine at Tanjungpura University on 30 July 2019 by ethical qualification number 5035 / UN22.9 / TA.00.03 / 2019.

\section{RESULT}

\section{The Characteristics of Respondents}

The research respondents consisted of $52 \%$ male and $48 \%$ female. The age of respondents ranged from 15-19 years. The respondents are mostly 16 years (41\%). The Sciences and Social Sciences majors shared the similar proportion of the rrespondents (50\%).

The Malays ethnicity composed the largest proportion of respondents, followed by the Javanese, Dayak and Bugis. Dayak ethnic is the native Kalimantan tribe which has the highest population in West Kalimantan but only ranks sixth highest (33\%) in Pontianak. ${ }^{9}$ Bugis is migrants from South Sulawesi and rank as fourth largest community in Pontianak City and phylogenically related to the Makassar tribe which has many $\mathrm{HbO}$ mutations. ${ }^{10}$. The process of acculturation among the ethnicities has been taken place in the City of Pontianak through marriages. ${ }^{9}$ 


\section{Level of Knowledge}

This study was done to find out the high school students' level of knowledge about thalassemia in Pontianak City. Moreover, the gender and the major of learning was used to determine the characteristics.

Almost half of the respondents had poor level of knowledge with almost one third has average level. In general, most of the respondents have lower level of knowledge on thalassemia (Figure 1). Female students and natural science basic study have a better understanding (Figure 2 and 3 ).

\section{The Level of Knowledge}

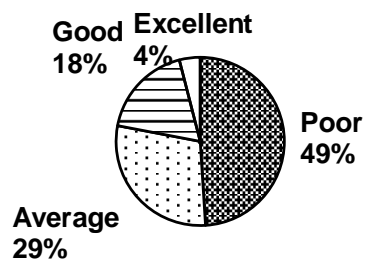

Figure 1. Knowledge Level of Respondents

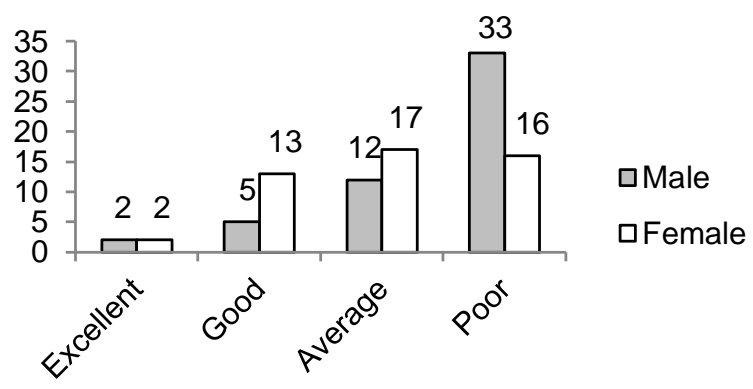

Figure 2. Knowledge Level Based on Gender

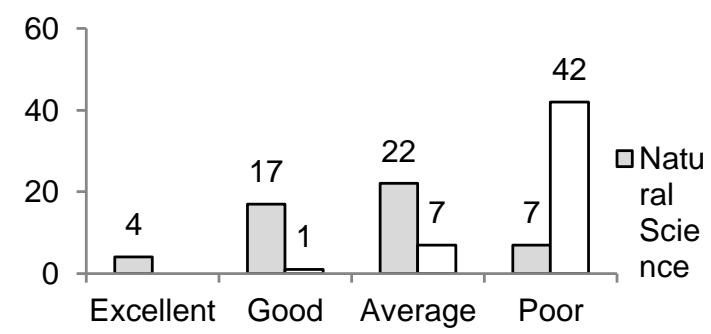

Figure 3. Knowledge Level Based on Major Study

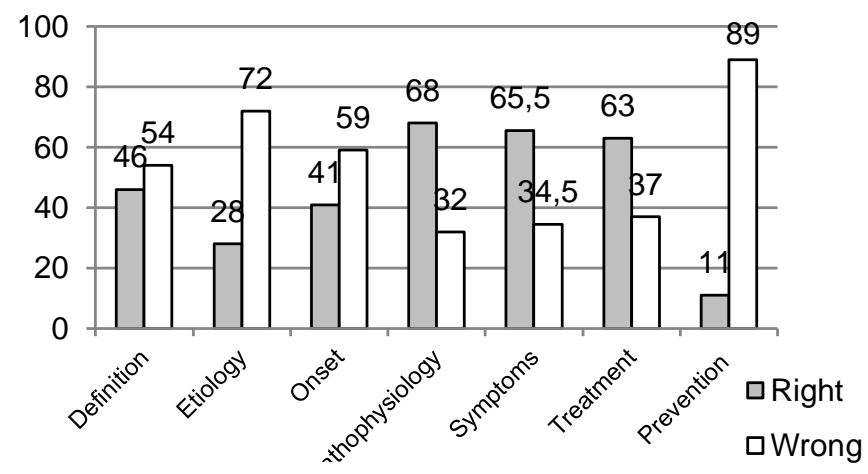

Figure 4. Recapitulation of Respondents' Answers per Question Topic

Figure 4. shows that preventive measure was the least understood topic with almost all respondents answered incorrectly. Followed by the cause, onset and definition of thalassemia. While, pathophysiology, symptoms and treatment are 3 topics that most of the respondents were understood.

Most respondents (63\%) had never heard of information about thalassemia before, while other respondents (37\%) had heard information about thalassemia from various media information detailed in the following diagram.

Figure 5 shows almost half of the respondents gained their knowledge from the internet, whereas health workers and school were sharing the same proportions. Relatives or friends shared the same number as printed media. These results show the opportunity for the usage of social media as an important vehicle in distributing the health promotion material.

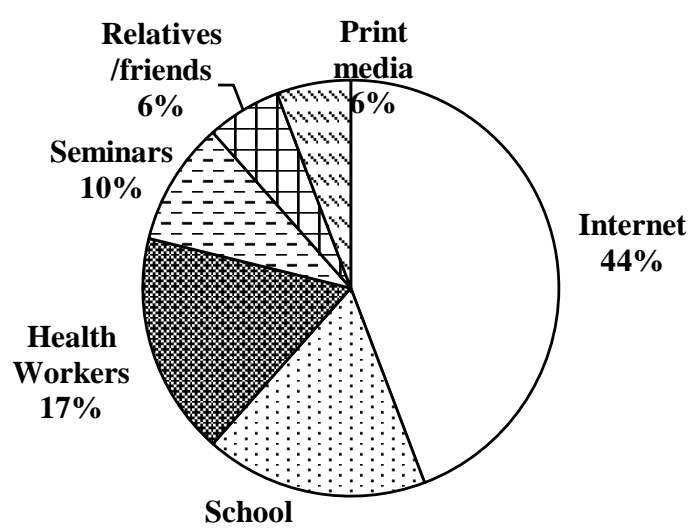

Figure 5. Source of Information ( $=47$ ) 


\section{DISCUSSION}

Thalassemia is an autosomal recessive genetic disease that causes the disturbance of the formation of red blood cells in the patient's body. ${ }^{11}$ This condition requires the patient to undergo routine and long-life treatment such as routine blood transfusion and the administration of iron chelation to prevent complications due to the toxic excess of iron in the blood. ${ }^{12}$ Preventive measure is essential in determining the possibility of any genetical disorder. Genetic screening in pregnancy is considered very important to be done for any couple with the possession of thalassemia genes. ${ }^{11}$ indeed, awareness to genetic screening requires a good understanding of thalassemia. ${ }^{13}$

This study shows that most respondents have poor knowledge. Studies varies in regard to the level of knowledge among teenagers. A study from Iran revealed the same results with less than $20 \%$ of students have a good level of understanding about thalassemia. ${ }^{14}$ While, other studies from India shows much better results with most respondents have good understanding. ${ }^{15,16}$

Female respondents have better level of knowledge than male respondents in this study. Studies varies in regard to the gender in understanding the issue. Research in Iran states that female students who have good knowledge of thalassemia are much more than male students. ${ }^{14}$ Study by Basu revealed different results by stating male respondents have better knowledge than women. ${ }^{16}$

This study shows that the respondents from natural science major has better knowledge than the respondents from social science major. The knowledge level of high school students about thalassemia is better for students with majors related to health and applied sciences than students in other majors. ${ }^{17}$ Respondents from natural science major have gained an understanding of the basis of genetic science and related diseases so that they have better level of knowledge than respondents from other majors. ${ }^{15,18}$ Someone who has a background in natural science tends to have an interest in the field of science in choosing reading material or sources of information so that the opportunity to be exposed to information especially in thalassemia is greater. ${ }^{19}$ This tendency can make respondents from a scientific background have a better level of knowledge.

The general knowledge of respondents about thalassemia is good enough on several topics, namely pathophysiology, symptoms and treatment of thalassemia. Several other topics such as definition, etiology, onset and prevention are still poorly understood by respondents (Figure 4).

Respondents are difficult to distinguish between thalassemia and hemophilia. Hemophilia is a blood clotting disorder which is characterized by severe and chronic bleeding in patients when the injury occured, so it requires special treatment. This disease is a genetic disease. ${ }^{20}$

The topic of aetiology needs to be emphasized on health promotion related to thalassemia because most respondents consider bacteria and unhealthy lifestyles can cause thalassemia. A lack of understanding of the role of genetics in the thalassemia aetiology has an impact on respondents' understanding of the topic of thalassemia prevention. Some of respondents do not know the role of genetic screening as a preventive measure for thalassemia. It is seen that the majority of respondents choose to maintain their diet and have a healthy lifestyle that can prevent the addition of new thalassemia patients.

Respondents also have lack of understanding on the topic of thalassemia onset. Most respondents answered thalassemia suffered since birth, but more than half of respondents assumed that thalassemia could be suffered by someone who was previously normal.

Although most respondents understand that blood transfusion is the treatment of thalassemia, quite a number of respondents chose the dialysis answer for that question. Dialysis or hemodialysis is routine treatment for patients with end-stage renal failure and is not associated with thalassemia. ${ }^{20}$

Most respondents said they had never heard information about thalassemia before, while almost one third stated they had heard. The number of respondents who knew of thalassemia earlier in this study was much lower compared to previous studies in several different countries. Research by Ebrahim et al. revealed that $53 \%$ of respondents had heard information about thalassemia before. ${ }^{21}$ Balcin revealed that more than half of the respondents (57.7\%) had heard of thalassemia before, while research in India had a much higher number, as many as $85 \%$ of respondents had heard the term disease. ${ }^{22}$

The low awareness of the term thalassemia in this study shows that thalassemia is a disease that has not been widely discussed in society, but its prevalence is quite high. Indonesia is one of the thalassemia belt countries which has a relatively high number of thalassemia sufferers. Management of thalassemia which requires lifelong treatment can be a psychological and financial burden on families and countries. Preventive program such as genetic counseling is one step that can be taken by the country to reduce the number of thalassemia 
cases. $^{23,24}$ People awareness on thalassemia as a genetic disease has massive impact to successing the thalassemia preventive program up to $40 \%$ of overall program besides increasing public awareness genetic counseling (33\%) and premarital screening $(27 \%) .{ }^{25}$

A person who have a thalassemia gene (carrier thalassemia) are often not known before laboratory tests because they do not experience severe symptoms like thalassemia major patients. Anemia is a symptom that can be found in thalassemia carriers and is commonly known by the public. ${ }^{26}$ Knowledge of thalassemia including its severity, causes and symptoms can be the first step to increase public awareness, especially genetic screening students to confirm the thalassemia gene itself.

Sources of information selected by respondents to gain knowledge about thalassemia are internet, school, health workers, seminars, relatives/friends and print media. Information sources used by the public in Kolkata are also dominated by health workers $(37.38 \%)$, electronic media (31.77\%) and relatives/friends (29.21\%). ${ }^{16} \mathrm{Al}$ Qahtani said online media or internet are the right method to increase public awareness and knowledge of thalassemia. ${ }^{27}$ The use of the internet has become very common and often used by people nowadays. A survey conducted by the Indonesian Internet Service Providers Association stated that teenagers, in range age of 15-19 years are the highest population (91\%) who received penetration of internet in 2018. ${ }^{28}$ The data also states that students are the highest internet user population in Indonesia. West Kalimantan specifically also has the highest internet user penetration rate (80\%) on Kalimantan island. ${ }^{28}$ The internet can be an information sharing platform to increase public awareness and knowledge about thalassemia. Audiovisual media can be a good choice to attract the attention of adolescents. Audio-visual media such as animated videos are considered more effective in conveying information to students. The use of audiovisual media can stimulate the sense of hearing and vision of students simultaneously so the process of receiving new information can be more effective. ${ }^{29}$

School and health workers are the second highest source of information chosen by respondents. Respondents who are students as well have chosen school and books as the main source of information about thalassemia. ${ }^{15}$ Majors in high school make difference opportunity between natural science and social science students who do not discuss basic genetic science in the curriculum to get exposure of information about thalassemia. ${ }^{18}$ Most respondents who have health-related backgrounds received information from books. ${ }^{30}$ Ahmed said respondents who were not from science or health backgrounds received information mostly from television (36\%), friends (32\%) and social media (24\%). ${ }^{30}$ School health programs which consist of regular counseling and seminars that include all majors in high school about thalassemia and other genetic diseases can be a step of thalassemia prevention programs in schools. Seminars in general can be delivered through conventional methods such as lectures or through group discussion methods that involve extension respondents in the process of delivering information. Group discussion is more effective because it can increase students' understanding of new information by up to $50 \%$ compared to lecture methods which only produce student understanding of $20 \%{ }^{31}$ Thalassemia education as prevention program should be done as soon as possible to teenagers because education is a major factor in increasing knowledge about thalassemia. ${ }^{22}$

Apart from the adequate results to answer the research question, limitation also appears. Since this study aimed at gaining knowledge among teenager and the emerging of internet as one main results, exploration on how social media is influencing their level of knowledge needs to be seek further. The experience and perception of thalassemia survival is also an important part to be investigated to shed some lights in how they survived from this ailment.

\section{CONCLUSION}

It can be concluded thet most of the high school students in Pontianak City have poor knowledge of thalassemia. If it is iseen from the gender, female respondents have better knowledge than male. Since most of students use internet as a source of information other than conventional, thus preventive program need to consider internet in utilizing the internet.

\section{References}

1. Abbas AK, Aster JC, Kumar V, Robbins SL. Robbins Basic Pathology (10th edition). 2018. Philadelphia: Elsevier. Pp 421-6.

2. Menteri Kesehatan Republik Indonesia. Keputusan Menteri Kesehatan Republik Indonesia Nomor HK.01.07/MENKES/1/2018 tentang Pedoman Nasional Pelayanan Kedokteran Tata Laksana Thalasemia. 2018. 
Jakarta: Kementerian Kesehatan Republik Indonesia.

3. Alyumnah P, Ghozali $M$, Dalimoenthe $\mathrm{NZ}$. Skrining Thalassemia Beta Minor pada Siswa SMA di Jatinangor. JSK, 2016;1(3):133-8. doi.org/10.24198/jsk.v1i3.10358.

4. Kementerian Kesehatan Republik Indonesia. Hari Thalasemia Sedunia 2018: Bersama untuk Masa Depan yang Lebih Baik, (Online, 2018. www.depkes.go.id, accessed 25 March 2019).

5. Inati $A$, Zeineh $\mathrm{N}$, Isma'eel $\mathrm{H}$, Koussa $\mathrm{S}$, Gharzuddine W, \& Taher A. Beta-thalassemia: the Lebanese experience. Clinical and laboratory haematology. 2006:28(4), 217-227. https://doi.org/10.1111/j.1365-

2257.2006.00792.x

6. Ashraf S, and Bernadette M. Iranian National Thalassaemia Screening

Programme. BMJ 2004; $329: 1134$

7. Sari NM, Wirawan SB, Entijayanti FP, Afriliani K, Deliesya FN, Karimah AN, dan Fadhilah F. Beban Ganda Anemia Pada Remaja Smpn Tempuran Kabupaten Karawang. Dharmakarya: Jurnal Aplikasi Ipteks Untuk Masyarakat. 2018:7(2), 141145. doi.org/10.24198/dharmakarya.v7i2.20208

8. Pranajaya R, dan Nurchairina. Faktor yang Berhubungan dengan Kualitas Hidup Anak Thalasemia. Jurnal Keperawatan, 2016: XII(1), 130-139.

9. Rachmadhani A. Dimensi Etnik dalam Kerukunan Umat Beragama di Kota Pontianak Provinsi Kalimantan Barat. Panangkaran Jurnal Penelitian Agama dan Masyarakat, 2018;2(1):1-21. doi.org/10.14421/panangkaran.2018.0201-01.

10. Gupta AD, Nadkarni A, Mehta P, Goriwale M, Ramani M, Chaudhary $P$, et al. Phenotypic expression of $\mathrm{HbO}$ Indonesia in two Indian families and its interaction with sickle hemoglobin. Indian $J$ Pathol Microbiol, 2017;60:79-83. doi.org/10.4103/03774929.200030.

11. Marcdante KJ, Kliegman RM. 2015. Nelson Essentials of Pediatrics (7th edition). Philadelphia: Elsevier. pp148-518.

12. Rund D. Thalassemia: Modern Medicine Battles an Ancient Disease. American Journal of Hematology, doi.org/10.1002/ajh.24231.

13. Dewanto JB, Tansah H, Dewi SP, Napitu H, Panigoro R, Sahiratmadja E. Increased Knowledge of Thalassemia Promotes Early Carrier Status Examination among Medical Students. Universa Medicina, 2016;34(3):220. doi.org/10.18051/UnivMed.2015.v34.220-228.

14. Miri-Moghaddam E, Motaharitabar EM, Erfannia E, Dashipour A, Oushvar M. High
School Knowledge and Attitudes towards Thalassemia in Southeastern Iran. International Journal of Hematology-Oncology and Stem Cell Research, 2014;8(1):24-30. www.ncbi.nlm.nih.gov/pmc/articles/PMC39131 53/\#_ffn_sectitle.

15. Palash D, Srijana M, Kamalika D. Knowledge and Attitude Regarding Premarital Screening of Beta Thalassemia among The Students of Selected College of South-24-Parganas, West Bengal, India. India Journal Research, 2018;7(10):24-26. doi.org/10.36106/paripex.

16. Basu M. A Study on Knowledge, Attitude, and Practice about Thalassemia among General Population in Outpatient Department at A Tertiary Care Hospital of Kolkata. Journal of Preventive Medicine and Holistic Health, 2015;1(1):5-12.

www.researchgate.net/publication/282657666

17. Kumar M, Valli SM, Sharma VL, Goel NK, Sehgal A. A Study Regarding Awareness among The University Students about The Disease Beta Thalassemia. Public Health Open Access, 2019;3(2):1-7. doi.org/10.23880/phoa-16000137.

18. Tursinawati Y, dan Fuad W. Pengetahuan Pengaruhi Sikap dan Tindakan Mahasiswa terhadap Program Pencegahan Thalassemia di Indonesia. Higeia Journal, 2018;2(4):654-62. doi.org/10.15294/higeia.v2i4.25407.

19. Harris KL. A Background in Science: What Science Means for Australian Society. Australia: University of Melbourne. 2012.

20. Kasper LD, Fauci AS, Longo DL, Braunwald E, Hauser SL, Jameson JL. Harrison's Principles of Internal Medicine (19th edition). 2015. United State: Mc Graw Hill. Pp 598-600.

21. Ebrahim S, Raza AZ, Hussain M, Khan A, Kumari $\mathrm{L}$, Rasheed $\mathrm{R}$, et al. Knowledge and Beliefs regarding Thalassemia in an Urban Population. Cureus, 2019; 11(7). doi.org/10.7759/cureus.5268.

22. Balcin YI, Ergin A, Polat A, Atilgan T, Uzun U, Koyuncu H. Thalassemia Premarital Screening Program: Public View. What has been Done, What Needs to be Done?. International Journal of Hematology and Oncology, 2014;24(4):247252. doi.org/10.4999/uhod.14569.

23. Alhosain A. Premarital Screening Programs in The Middle East, From A Human Right's Perspective. Global Health Care Concerns, 2018;15(2):41-45.

24. Saffi M, Howard N. Exploring the Effectiveness of Mandatory Premarital Screening and Genetic Counselling Programmes for B-Thalassemia in The Middle East: A Scoping Review. Public 
Health Genomics, 2015;18:193-203. doi.org/10.1159/000430837.

25. Karimzaei T, Masoudi Q, Shahrakipour M, Navidiyan M, Jamalzae AA, Bamri AZ. Knowledge, Attitude and Practice of Carrier Thalassemia Marriage Volunteer in Prevention of Major Thalassemia. Global Journal of Health Science, 2015;7(5):364-370. doi.org/10.5539/gjhs.v7n5P364.

26. Brancaleoni V, Di Pierro ED, Motta I, Cappellini MD. Laboratory Diagnosis of Thalassemia. International Journal of Laboratory Hematology, 2016;38(1):32-40. doi.org/10.1111/ijlh.12527.

27. AlQahtani RS, Bedalwi AA, Alburkani AM, AlFahed MM, Alhoraibi RA, Tarawah AM. Knowledge and Response of The Community to Premarital Screening Program (Sickle Cell Anemia/Thalassemia); Almadinal, Saudi Arabia. Journal of Applied Hematology, 2018;9(2):59-62. doi.org/10.4103/joah.joah_1_18.

28. Asosiasi Penyelenggara Jasa Internet Indonesia. 2018. Responden Survei Nasional Penetrasi Pengguna internet, (Online), (https:/lapjii.or.id/survei2018/.

29. Rakhmilla LE, Susanah S, Rohmawaty E, Effendi SH. Effectiveness of an Educational Intervention in Providing Knowledge about The Prevention of Thalassemia: An Effort to Reduce New Thalassemia Cases. Asian Journal of Epidemiology, 2018;11(2):59-64. doi.org/10.3923/aje.2018.59.64

30. Ahmed D, Zafar H, Tauseef K, Nawaz MN, Ammar M. Identification of Common Ways for Thalassemia Awareness in Medical and NonMedical Professional. UK Journal of Pharmaceutical and Biosciences, 2017;5(5):1-5. doi.org/10.20510/ukjpb/5/i5/166548.

31. Davis B, Summers M. Applying Dale's Cone of Experience to Increase Learning and Retention: A Study of Student Learning in A Foundational Leadership Course. Qscience Proc, 2015;6. doi.org/10.5339/qproc.2015.elc2014.6. 